ఠ

\title{
A cross-sectional study on perception of stigma by Chinese schizophrenia patients [Expression of concern]
}

Ren Z, Wang H, Feng B, et al. A cross-sectional study on perception of stigma by Chinese schizophrenia patients. Neuropsychiatric Disease and Treatment. 2014;10:535-540.

Concerns were raised about the paper in an email to the Editors from a reader. The reader called into question the validity of the conclusions along with the methodology used in analyzing the statistical findings. Dove Medical Press editors have attempted on many occasions and via different methods to contact the authors of this paper. The editors sought to obtain the authors responses to the questions raised by the reader which were supported by similar concerns expressed by independent biostatisticians.

We urge the authors to contact us to address these matters as if we do not hear from them we will have little option but to retract the paper.

\section{Publish your work in this journal}

Neuropsychiatric Disease and Treatment is an international, peerreviewed journal of clinical therapeutics and pharmacology focusing on concise rapid reporting of clinical or pre-clinical studies on a range of neuropsychiatric and neurological disorders. This journal is indexed on PubMed Central, the 'PsycINFO' database and CAS, and is the official journal of The International Neuropsychiatric Association (INA). The manuscript management system is completely online and includes a very quick and fair peer-review system, which is all easy to use. Visit http://www.dovepress.com/testimonials.php to read real quotes from published authors. submit your manuscript | www.dovepress.com

Dovepress

http://dx.doi.org/|0.2147/NDT.S7 | 120 